\title{
Analysis of Coke Oven Gas Injection from Dome in COREX Melter Gasifier for Adjusting Dome Temperature
}

\author{
Heng Zhou ${ }^{1}$, Shengli $\mathrm{Wu}^{1}$, Mingyin Kou ${ }^{1, * \mathbb{C}}$, Shun Yao ${ }^{1}$ and Yansong Shen ${ }^{2} \mathbb{C}$ \\ 1 School of Metallurgical and Ecological Engineering, University of Science and Technology Beijing, \\ Beijing 100083, China; zhouheng@ustb.edu.cn (H.Z.); wushengli@ustb.edu.cn (S.W.); \\ yaoshunapp@163.com (S.Y.) \\ 2 School of Chemical Engineering, University of New South Wales, Sydney, NSW 2052, Australia; \\ ys.shen@unsw.edu.au \\ * Correspondence: koumingyin@ustb.edu.cn; Tel.: +86-010-6233-4989
}

Received: 21 October 2018; Accepted: 1 November 2018; Published: 8 November 2018

\begin{abstract}
Coke oven gas (COG) injection from the dome in a COREX melter gasifier is a good method to not only reduce the amount of solid fuel used for gasification, but also to adjust the freeboard temperature that should be maintained within a certain range. In this paper, the characteristics of COG injection used to adjust dome temperature are studied through a static model. The results show that an increase in melting rate causes a decrease in dome temperature and generator gas volume. However, with an increase in coke rate, dome temperature increases, while generator gas volume decreases. For low coke rate conditions, the dome temperature is generally found to be lower than $1050^{\circ} \mathrm{C}$, and COG is blasted for combustion and heat releasing. For high coke rates, the dome temperature is generally higher than $1050^{\circ} \mathrm{C}$. Under the premise that oxygen reduction cannot meet the demand, COG is used for decomposition. After the COG injection, the amount and reduction capacity of the generator gas can meet the needs of reduction in shaft furnace. The findings of this work can be used as a theoretical basis to guide plant operations for COG injection.
\end{abstract}

Keywords: COREX melter gasifier; coke oven gas; dome temperature; static model

\section{Introduction}

COREX is the world's first commercially established and industrially proven smelting-reduction process $[1,2]$. It is a two-stage process that involves pre-reduction in a shaft furnace, followed by final reduction and separation in a melter gasifier, as shown in Figure 1 [3-5]. The second COREX-3000 module in Baosteel was moved from Shanghai to Xinjiang in a bid to utilize local coal resources [6]. Owing to the special properties of coking coal (high reactivity) $[7,8]$, coke consumption in the blast furnace of Basteel is high $[9,10]$. Therefore, the coke oven gas (COG) is surplus. The COG with high heat value and high $\mathrm{H}_{2}$ percentage is projected to blast into the COREX process for improving reduction efficiency and reducing solid fuel consumption.

Coke oven gas has been successfully injected into blast furnace in industrial practice in China and abroad [11-15]. However, the difference between a blast furnace and a COREX process makes it impossible for the latter to draw experience directly from COG injection in a blast furnace. Wu et al. [16] investigated the characteristics of COG injection from tuyere in a COREX melter gasifier. As normal temperature oxygen is blasted into a COREX melter gasifier, COG injection from tuyere in COREX lacks the thermal compensation measures that are usually used in blast furnaces. The insufficient heat in the melter gasifier caused by COG tuyere injection is the main reason for the quantity of COG being limited. However, it is important to note that the secondary injection systems are installed in the dome 
zone of melter gasifier to recycle dust and oxygen [17]. The COG can be blasted into the COREX melter gasifier through the burner in the dome zone. This not only reduces the amount of solid fuel used for gasification, but also adjusts the freeboard temperature, which should be maintained within a certain range. However, no detailed descriptions of the characteristics of COG injection from the dome in a COREX melter gasifier are available.

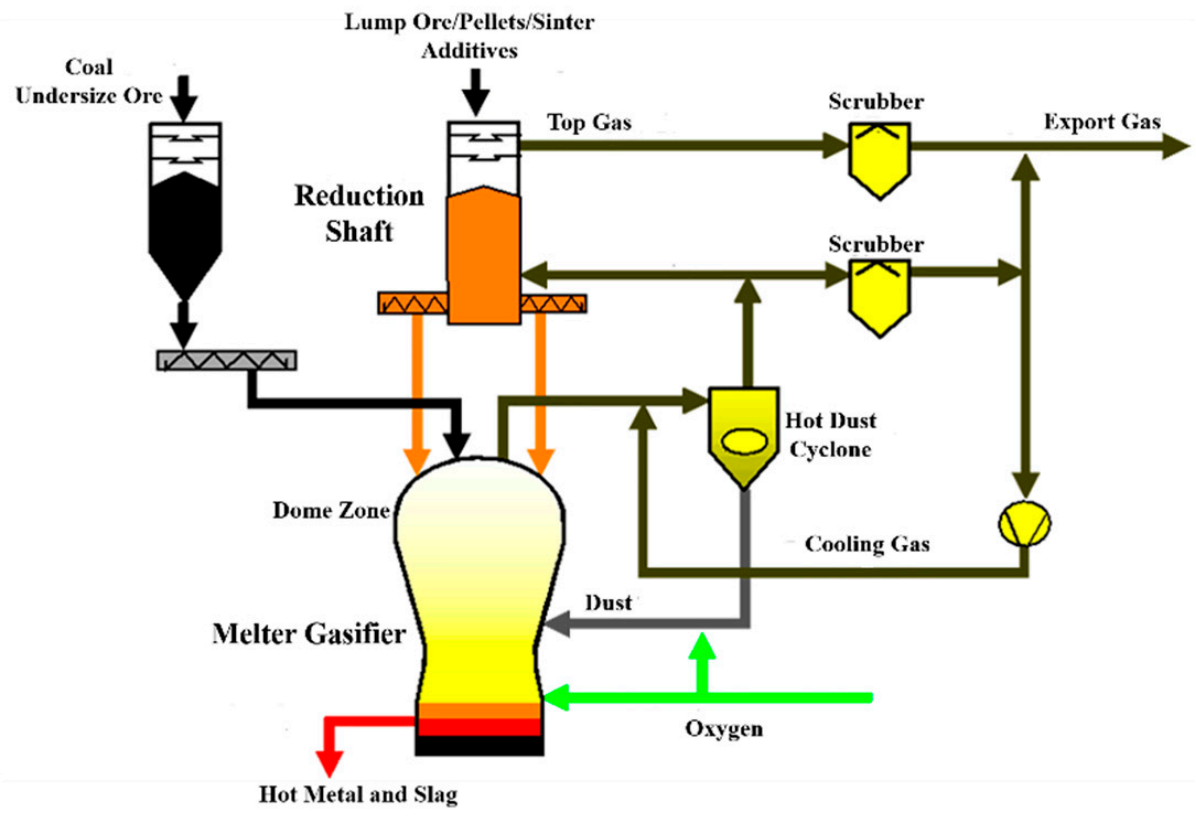

Figure 1. Schematic diagram of the COREX process.

In this study, COG injection from dome in a COREX melter gasifier for adjusting dome temperature is investigated. The effect of COG injection on lowering fuel rate will be discussed elsewhere. The dome zone is a unique characteristic of the COREX process, and dome temperature should be maintained at approximately $1050{ }^{\circ} \mathrm{C}$ to meet the thermal demand for an endothermic reaction, as well as to ensure the cracking of coal [18]. The fluctuation of dome temperature is undesirable for maintaining a stable operation. Inadequate dome temperature could lead to the hydrocarbons in the coal not cracking completely and tar concentrations clogging the generator gas nozzle [19], while excessive freeboard temperature may result in the burnout of the refractory and the device in the freeboard, especially the distribution system. In addition, the dust in the generator gas with a higher temperature could soften and bond to block the generator gas nozzle. The key factors affecting dome temperature [20], recycling dust combustion [21,22], and distribution of dome temperature [23] have been sensitively analyzed. However, COG injection from dome to adjust dome temperature has not been fully understood, particularly, the fact that COG could affect dome temperature through combustion or decomposition, without significantly changing the reducing gas composition. Thus, a detailed investigation of the characteristics of COG injection from dome to adjust dome temperature is necessary for obtaining a well-controlled and optimal system performance.

The current paper presents a static model to explore material flow and energy flow in the COREX process. The effect of melting rate and coke rate on the temperature and volume of reducing gas in dome zone was discussed. The amount of COG injection from dome to adjust dome temperature under different melting rates and coke rates was then studied. The effect of COG injection from dome on the composition of reducing gas was also discussed. The findings of this work should be useful to control and optimize the COREX process with COG injection from the dome. 


\section{Static Model and Computation Method}

The core of the static model is the calculation of raw material (iron ore, fuel, and flux) consumption, based on the three balance equations of $\mathrm{Fe}, \mathrm{C}$, and binary basicity $\left(R_{2}\right)$. The slag amount is calculated on the basis of the slag balance equation. The input items of the static model are the composition of raw materials; distribution ratio of fuel and flux between shaft furnace and melter gasifier; $R_{2}$ value and $\mathrm{FeO}$ mass fraction of slag; $\mathrm{C}$, $\mathrm{Si}$ and $\mathrm{S}$ contents in hotmetal; $\mathrm{CO}_{2}, \mathrm{CH}_{4}$, and $\mathrm{H}_{2} \mathrm{O}$ mass fractions in top gas of melter gasifier; and other expected parameters such as cyclone dust removal efficiency, and distribution ratio of elements on hot metal, among others. The balance equations of $\mathrm{Fe}, \mathrm{C}, R_{2}$, and slag are listed as follows:

$$
\begin{gathered}
\sum_{i} m_{i} \times w_{\mathrm{Fe}_{i}}=m_{\mathrm{HM}} \times w_{[\mathrm{Fe}]}+m_{\mathrm{slag}} \times w_{(\mathrm{FeO})} \times 56 / 72 \\
\sum_{i} m_{i} \times w_{\mathrm{C}_{i}}=m_{\mathrm{HM}} \times w_{[\mathrm{C}]}+\left(V_{\mathrm{CO}}+V_{\mathrm{CO}_{2}}+V_{\mathrm{CH}_{4}}\right) \times 12 / 22.4 \\
R_{2}=m_{\mathrm{CaO}} / m_{\mathrm{SiO}_{2}} \\
m_{\mathrm{slag}}=\left(m_{\mathrm{CaO}}+m_{\mathrm{SiO}_{2}}+m_{\mathrm{Al}_{2} \mathrm{O}_{3}}+m_{\mathrm{MgO}}+m_{\mathrm{CaS}}+m_{\mathrm{P}_{2} \mathrm{O}_{5}}+m_{\mathrm{MnO}}+m_{\mathrm{TiO}_{2}}\right) /\left(1-w_{(\mathrm{FeO})}\right)
\end{gathered}
$$

where, $i$ denotes the raw materials including iron ore, coal, coke, limestone, dolomite, and quartzite; $m_{i}$ represents the mass of raw materials for producing $1 \mathrm{t}$ hot metal, $\mathrm{kg} ; w_{\mathrm{Fe} i}$ and $w_{\mathrm{C} i}$, respectively, represent the mass fraction of Fe or $C$ in raw material $i ; m_{\mathrm{HM}}$ is the mass of hot metal, which is $1 \mathrm{t}$ in this study; $m_{\text {slag }}$ is the mass of slag, $\mathrm{kg} ; w_{[\mathrm{Fe}]}$ and $w_{[\mathrm{C}]}$ denote the mass fraction of Fe or $\mathrm{C}$ in hot metal, $\% ; w_{(\mathrm{FeO})}$ denotes the mass fraction of $\mathrm{FeO}$ in slag, $\% ; V_{\mathrm{CO}}, V_{\mathrm{CO} 2}, V_{\mathrm{CH} 4}$ represents the volume of $\mathrm{CO}, \mathrm{CO}_{2}$ and $\mathrm{CH}_{4}$ in export gas for producing $1 \mathrm{t}$ hot metal, respectively, $\mathrm{m}^{3} / \mathrm{t} ; m_{j}\left(j=\mathrm{CaO}, \mathrm{SiO}_{2}\right.$, $\left.\mathrm{Al}_{2} \mathrm{O}_{3}, \cdots\right)$ represents the mass of $j$ in slag, $\mathrm{kg}$.

When the raw material consumption is obtained, the volume and composition of top gas both in shaft furnace and melter gasifier are calculated by solving the balance equations of $\mathrm{C}, \mathrm{H}, \mathrm{O}$, and $\mathrm{N}$ in each furnace. According to the reactions in each furnace, the characteristic parameters are calculated such as direct reduction rate and gas utilization rate.

For heat balance, energy conservation in the pre-reduction shaft furnace and melter gasifier is calculated. The heat balance equations are solved by calculating the "heat in" from input materials and heat from carbon burning. "Heat out" includes the heat taken away by the top gas and the absorption heat of direct reduction. On the other hand, the heat balance of the whole COREX process is investigated.

\section{Results and Discussion}

\subsection{Basic Results}

Figure 2 shows an example of a mass flow sheet of the COREX process under a typical condition. The calculation conditions are defined where the metallization degree of iron ore in the shaft furnace is $60 \%$, and the oxygen concentration is $99.5 \%$. The decomposition rate of the flux such as magnesium carbonate and calcium carbonate in the shaft furnace are set to $100 \%$ and $50 \%$, respectively. Under this condition, $1448 \mathrm{~kg}$ iron ores and $990 \mathrm{~kg}$ fuels (197.6 kg coke/semi-coke and $792.4 \mathrm{~kg}$ coal) are required for producing $1 \mathrm{t}$ hot metal. Meanwhile, an amount of $1730.74 \mathrm{Nm}^{3}$ is produced in the melter gasifier. The proportion of $\mathrm{CO}, \mathrm{CO}_{2}, \mathrm{H}_{2}$, and $\mathrm{H}_{2} \mathrm{O}$ in the melter gasifier generator gas is $64.74 \%, 9.47 \%, 18.54 \%$, and $2.5 \%$, respectively.

In order to validate the reliability of the model, the results of this model were compared with the results from plant data for slag basicity, as shown in Figure 3a. It can be observed that the predicted slag basicity matches well with the actual values. The maximum difference between predicted and actual values is $8 \%$ for the slag basicity in the range of 1.18 to 1.38 . Figure $3 \mathrm{~b}$ shows the comparison of 
calculated and actual export gas volume. The results show the similar tendency and predicted value are essentially consistent with the actual data. These agreements verify the applicability of the present static model for predicting the characteristics of COG injection from dome.

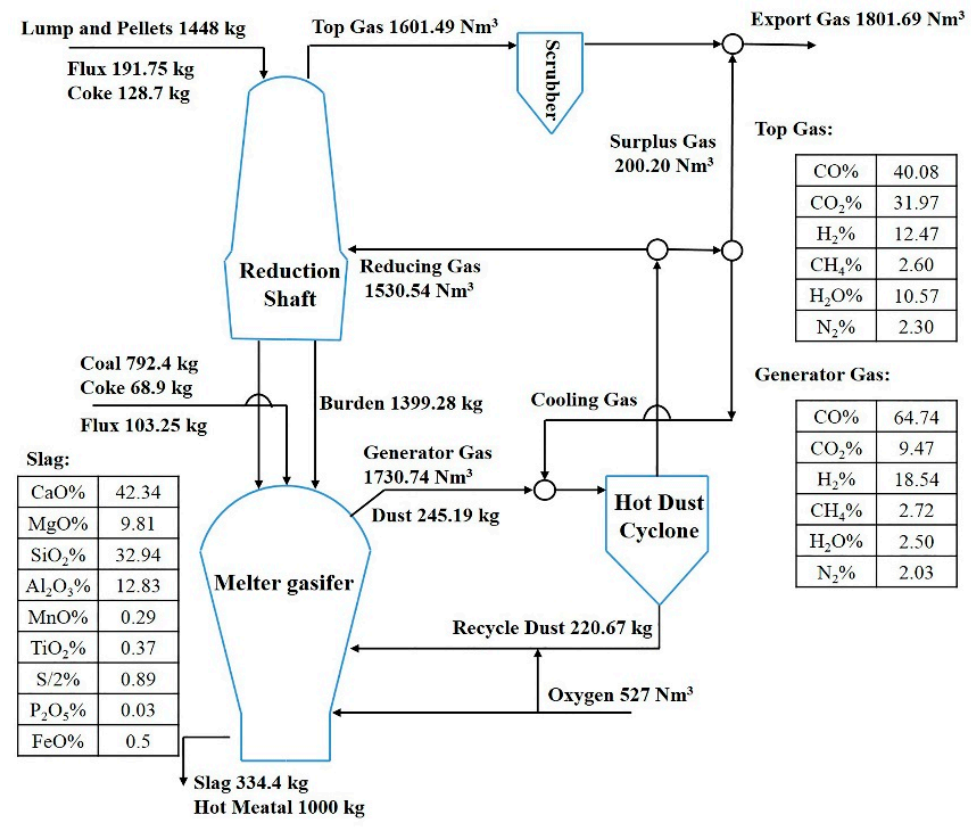

Figure 2. Specific mass flow in the COREX process.

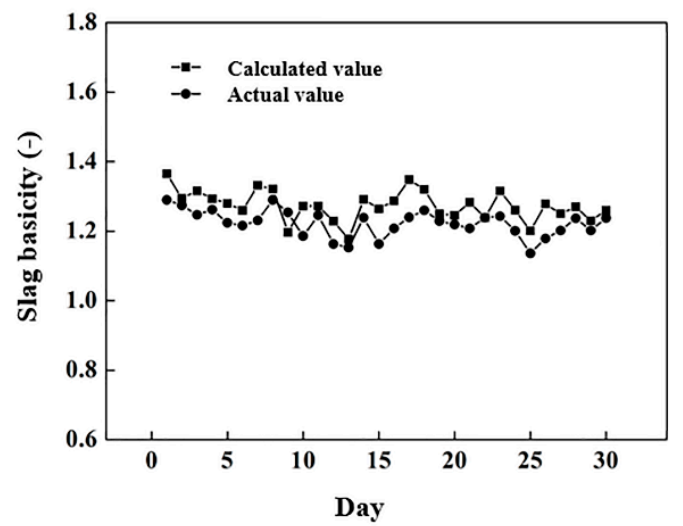

(a)

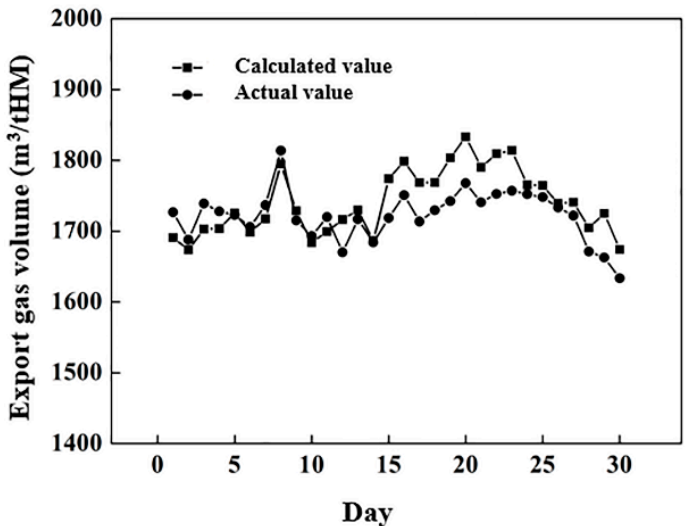

(b)

Figure 3. The comparison of actual and predicted values (a) slag basicity and (b) export gas volume.

\subsection{Effect of Melting Rate and Coke Rate}

In order to explore the influence of the melting rate, the relationship between the melting rate and fuel rate should first be solved, followed by clarifying the basic fuel rate under different melting rates. Figure 4 shows the variation trend of fuel rate with the melting rate. The data are collected from practice production values. The relationship is obtained through fitting and can be described as $y=$ $1272.98-2.21 x$, where $y$ denotes the fuel rate and $x$ represents the melting rate. The standard error of the slope and intercept of the equation are 0.2 and 27.6, respectively. Based on this relationship, the fuel structure under different melting rates is shown in Table 1 . It should be pointed out that the ratio of coke to the fuel is set as $20 \%$. In the following work, for each melting rate, the effect of coke rate will be discussed under the condition that the coal is replaced by coke without changing the fuel carbon content. 


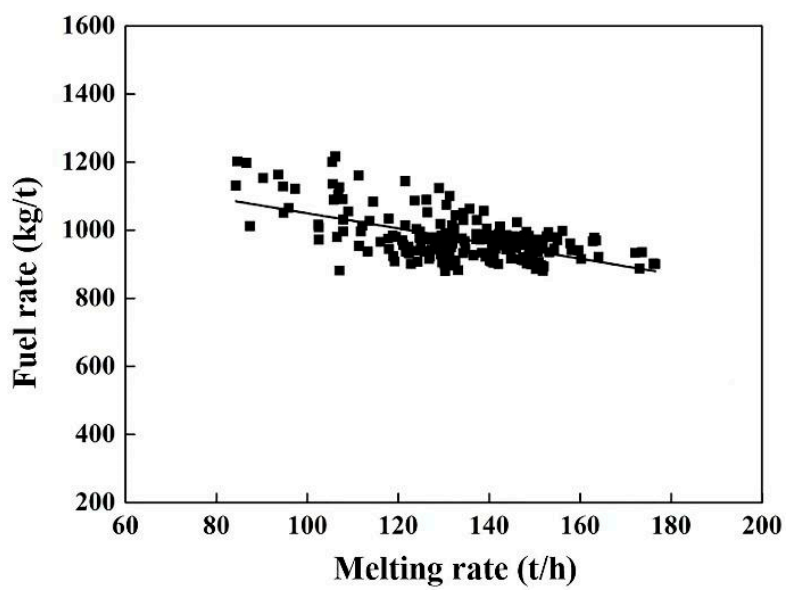

Figure 4. The variation trend of fuel rate with the melting rate.

Table 1. Fuel structure under different melting rates.

\begin{tabular}{cccc}
\hline Melting Rate (t/h) & Coke Rate (kg/t) & Coal Rate $\mathbf{( k g / t )}$ & Fuel Rate $(\mathbf{k g} / \mathbf{t})$ \\
\hline 140 & 202.02 & 810.08 & 1012.10 \\
150 & 197.60 & 792.40 & 990.00 \\
160 & 193.19 & 774.71 & 967.90 \\
170 & 188.78 & 757.02 & 945.80 \\
\hline
\end{tabular}

Figure 5a shows the effect of melting rate on dome temperature under different coke rates. When the coke rate is above $200 \mathrm{~kg} / \mathrm{t}$, the dome temperatures are higher than $1050{ }^{\circ} \mathrm{C}$, while the dome temperatures with coke rate of $150 \mathrm{~kg} / \mathrm{t}$ are lower than $1050{ }^{\circ} \mathrm{C}$. In addition, under the same coke rate, the dome temperature decreased when the melting rate increased. The main reason for this is that with the increase of melting rate, the fuel rate is reduced, as shown in Figure 4. The fuel consumption per hot metal decreases and the heat in melter gasifier reduces, leading to a drop of dome temperature. It can be seen from Figure 5a, the dome temperature increases with the increase of coke rate. This is attributable to the moisture and volatile matter amount in coke being lower than coal, demanding less heat and leading to a lower thermal load in dome zone. Figure 5b shows the influence of melting rate on volume of generator gas in dome zone under different coke rates. The generator gas volume is lower for a higher coke rate. This is caused by the volatile matter in coke is much less than that of lump coal, and the gas generated by the decomposition in dome zone is greatly reduced. The volume of generator gas decreases with the increase of melting rate for the lower fuel rate under higher melting rate.

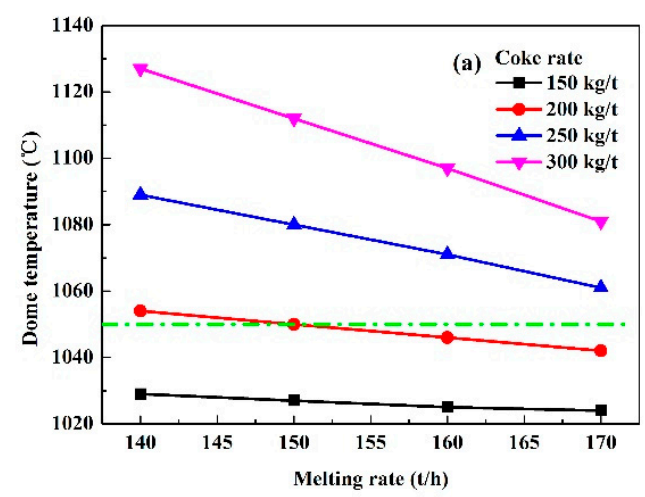

(a)

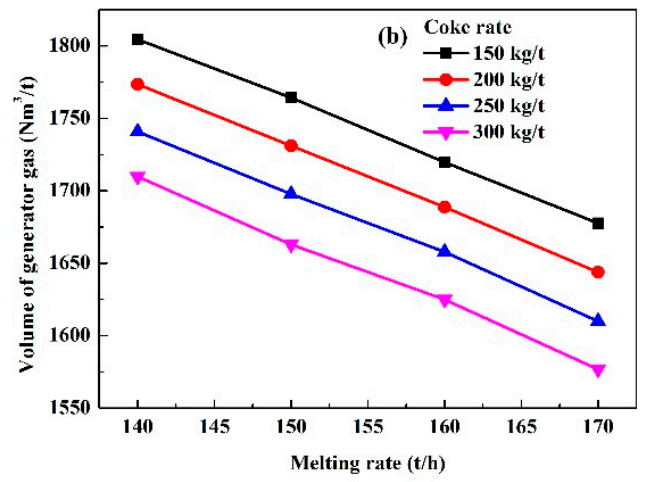

(b)

Figure 5. Effect of melting rate on (a) dome temperature and (b) volume of generator gas under different coke rates. 


\subsection{COG Injection for Adjusting the Dome Temperature}

In the actual production process, the means to directly adjust the dome temperature is controlling the oxygen flux of the burners located around the circumference of the dome zone. However, the adjustment is limited, especially for high dome temperature. The COG injection from the dome is an appropriate way to adjust the dome temperature through combustion or decomposition. The proportion of $\mathrm{CO}, \mathrm{CO}_{2}, \mathrm{~N}_{2}, \mathrm{H}_{2}$, and $\mathrm{CH}_{4}$ in the $\mathrm{COG}$ is $7 \%, 2 \%, 5 \%, 58 \%$, and $28 \%$, respectively.

Figure 6 shows the volume of COG injection from dome for controlling the dome temperature. In Figure 6, the positive values in the y-axis represent the volume of COG used for combustion while the negative values are the amount of COG used for decomposition. For the low coke rate conditions $(150 \mathrm{~kg} / \mathrm{t}$ and $200 \mathrm{~kg} / \mathrm{t}$ ), the dome temperature is generally lower than the appropriate one $\left(1050{ }^{\circ} \mathrm{C}\right)$, so the COG is blasted for combustion and heat releasing. The amount of the injected COG is approximately $3.3-21.1 \mathrm{Nm}^{3} / \mathrm{t}$. For high coke rates, the dome temperature is generally higher than $1050^{\circ} \mathrm{C}$. The COG is used for decomposition under the premise that the oxygen reduction cannot meet the demand. According to the difference between the dome temperature and the volume of the generator gas, the volume of the injected COG is $3.6-66.6 \mathrm{Nm}^{3} / \mathrm{t}$. In addition, there are two kinds of conditions that can adjust the dome temperature by decreasing the flow of oxygen. For example, under the conditions of having a melting rate of $140 \mathrm{t} / \mathrm{h}$ and coke rate $200 \mathrm{~kg} / \mathrm{t}$, and a melting rate of $170 \mathrm{t} / \mathrm{h}$ and coke rate $250 \mathrm{~kg} / \mathrm{t}$, the decrement of oxygen are $4.8 \mathrm{Nm}^{3} / \mathrm{t}$ and $11.3 \mathrm{Nm}^{3} / \mathrm{t}$, respectively. For the melting rate at $150 \mathrm{t} / \mathrm{h}$ and coke rate at $200 \mathrm{~kg} / \mathrm{t}$, the dome temperature is close to $1050{ }^{\circ} \mathrm{C}$, there is no COG injecting or oxygen reduction.

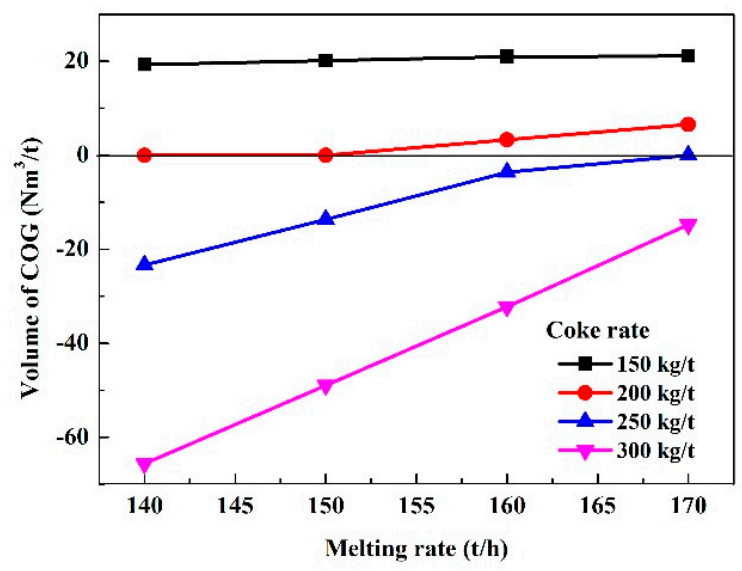

Figure 6. The volume of coke oven gas (COG) injection from dome for adjusting dome temperature.

The volume of generator gas after COG injection is shown in Figure 7. The amount of the generator gas is higher compared with the volume of generator gas before COG injection such as that shown in Figure $5 \mathrm{~b}$. The maximum value of the generator gas can reach $1834.5 \mathrm{Nm}^{3} / \mathrm{t}$, and the lowest value is $1600 \mathrm{Nm}^{3} / \mathrm{t}$. In this work, the metallization degree of iron ore in the shaft furnace is assumed as $60 \%$, denoting that the required amount of reducing gas in shaft furnace should be $1530.54 \mathrm{Nm}^{3} / \mathrm{t}$ as calculated in Section 3.1. Therefore, the reducing gas in melter gasifier after COG injection can meet the needs of reduction in shaft furnace.

Figure 8 shows the volume fraction of generator gas after COG injection under the melting rate $160 \mathrm{t} / \mathrm{h}$. When the coke rate increases from $150 \mathrm{~kg} / \mathrm{t}$ to $300 \mathrm{~kg} / \mathrm{t}$, the CO volume fraction decreases from $69.7 \%$ to $64.8 \%$, but the $\mathrm{H}_{2}$ volume fraction increases from $18.6 \%$ to $21.9 \%$. The main reason for this is that the COG is blasted for combustion under low coke rate and for decomposition under high coke rate. Further, the amount of the injected COG is especially higher in high coke rate condition. Therefore, the $\mathrm{H}_{2}$ volume fraction and $\mathrm{CH}_{4}$ volume fraction are increased with the increase of coke rate. Besides, the reduction capacity of the generator gas after COG injection under different coke rates is somewhat higher than that in the basic case, which is good for reduction in shaft furnace. 


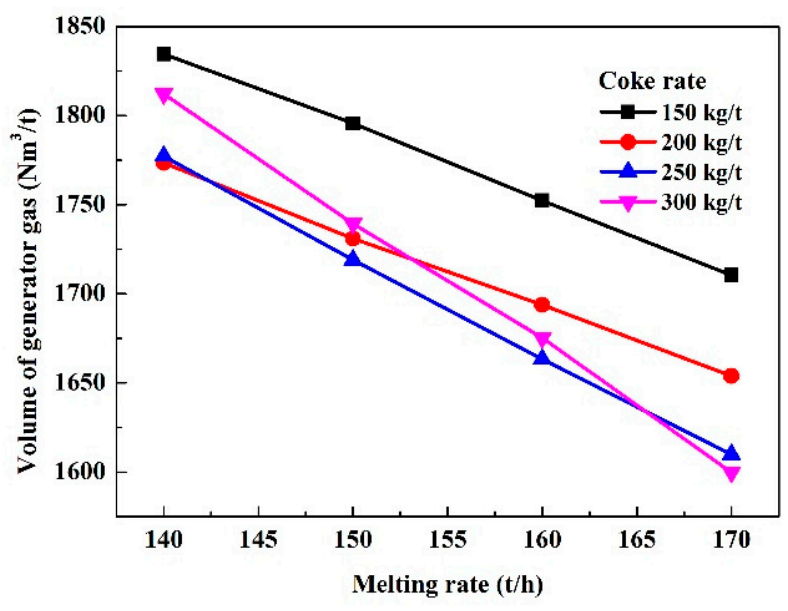

Figure 7. The volume of generator gas after COG injection.

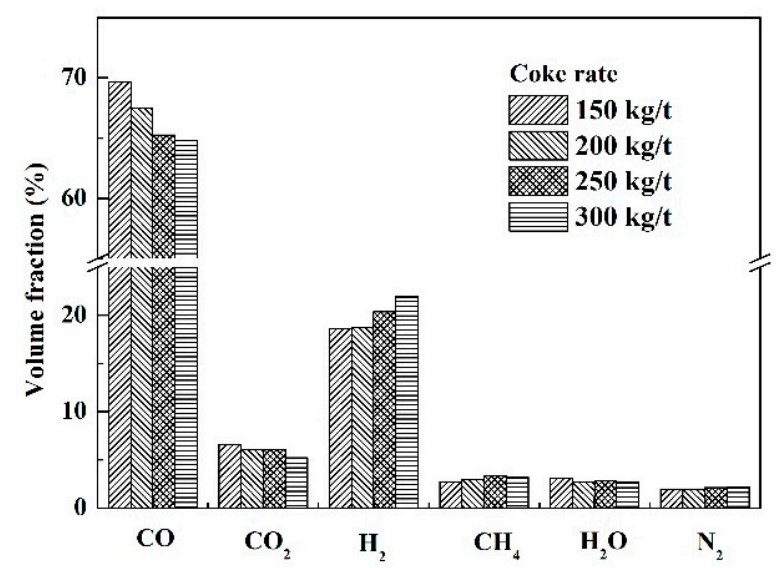

Figure 8. Volume fraction of generator gas after COG injection under the melting rate $160 \mathrm{t} / \mathrm{h}$.

\section{Conclusions}

A static model based on mass and heat balance is developed to investigate the characteristics of COG injection from dome in COREX melter gasifier. The model is validated by comparing the predicted value with actual plant data. With the increase of melting rate, both the dome temperature and volume of generator gas decrease. As the coal is replaced by coke without changing the fuel carbon content, the dome temperature increases while the volume of generator gas decreases with the increase of coke rate. For the low coke rate conditions $(150 \mathrm{~kg} / \mathrm{t}$ and $200 \mathrm{~kg} / \mathrm{t})$, the dome temperature is generally lower than $1050{ }^{\circ} \mathrm{C}$, and COG is blasted for combustion and heat releasing. The amount of the injected COG is approximately $3.3-21.1 \mathrm{Nm}^{3} / \mathrm{t}$. For high coke rates, the dome temperature is generally higher than $1050^{\circ} \mathrm{C}$. Under the premise that the oxygen reduction cannot meet the demand, the COG is used for decomposition. After the COG injection, the amount and reduction capacity of the generator gas can meet the needs of reduction in shaft furnace.

Author Contributions: Conceptualization, H.Z. and S.W.; methodology, H.Z. and S.Y.; validation, M.K.; formal analysis, H.Z. and Y.S.; writing_original draft preparation, H.Z.; supervision, S.W.; project administration, H.Z. and Y.S.; funding acquisition, H.Z. and S.W.

Funding: This research was funded by the National Natural Science Foundation of China (Grant Number: 51804027), the China Postdoctoral Science Foundation (Grant number: 2017M610769), and Fundamental Research Funds for the Central Universities (Grant number: FRF-TP-17-036A1).

Conflicts of Interest: The authors declare no conflict of interest. 


\section{References}

1. Anameric, B.; Kawatra, S.K. Direct iron smelting reduction processes. Miner. Process. Extr. Metall. Rev. 2008, 30, 1-51. [CrossRef]

2. Wang, N.; Xie, X.M.; Zou, Z.S.; Guo, L.; Xu, W.R.; Zhou, Y.S. Analysis of material and energy consumption of COREX C3000. Steel Res. Int. 2008, 79, 547-552. [CrossRef]

3. Qu, Y.X.; Zou, Z.S.; Xiao, Y.P. A comprehensive static model for COREX process. ISIJ Int. 2012, 52, $2186-2193$. [CrossRef]

4. Guo, Y.L.; Xu, W.R.; Zhu, J.M.; Zhang, J.Y. The burden structure and its consumption in the melter gasifier of the COREX process. Metall. Mater. Trans. 2013, 44, 1078-1085. [CrossRef]

5. Kumar, P.P.; Gupta, P.K.; Ranjan, M. Operating experiences with Corex and blast furnace at JSW Steel Ltd. Ironmak. Steelmak. 2008, 35, 260-263. [CrossRef]

6. Yang, C.B.; Zou, Q.F. Improvement in Primarily COREX Technology of Bayi Steel. Xingjiang Iron Steel 2014, 33-35. (In Chinese)

7. Wang, F.; Wu, Q.; Zhu, Z.Z.; Shi, G.J.; Bai, D.Y. Differences between Xinjiang and inland coking coals. Clean Coal Technol. 2018, 24, 80-84.

8. Wang, Z.P. Preliminary discussion on coal quality and utilization direction for Xinjiang coal. Coal Qual. Technol. 2009, 1, 6-9.

9. Wu, R.Q. Analysis of coke rate of blast furnace in Bayi Steel. Xingjiang Iron Steel 2008, 8-12.

10. Yang, S.P.; Yang, D.L.; Feng, Y.B.; Sun, G. Bell-less charging system of blast furnace at Bayi Steel. China Metall. 2006, 10-12. (In Chinese)

11. Diemer, P.; Killich, H.J.; Knop, K. Potentials for utilisation of coke oven gas in integrated iron and steel works. Stahl und Eisen 2004, 124, 21-30.

12. Andahazy, D.; Slaby, S.; Löffler, G.; Winter, F.; Feilmayr, C.; Burgler, T. Governing processes of gas and oil injection into the blast furnace. ISIJ Int. 2006, 46, 496-502. [CrossRef]

13. Qi, Y.H.; Yan, D.L.; Gao, J.J.; Zhang, J.C.; Li, K.M. Study on industrial test of the Oxygen blast furnace. Iron Steel 2011, 46, 6-8.

14. Zhang, W.; Wang, Z.Y.; Zhang, L.G.; Wang, X.L.; Ding, W. Analysis on comprehensive injection technology for blast furnace in Ansteel. Ansteel Technol. 2014, 8-12. (In Chinese)

15. Razzaq, R.; Li, C.S.; Zhang, S.J. Coke oven gas: Availability, properties, purification, and utilization in China. Fuel 2013, 113, 287-299. [CrossRef]

16. Wu, S.L.; Zhang, Z.K.; Kou, M.Y.; Shen, W.; Du, K.P. Characteristics and analyses of COG injection from tuyere in COREX melter gasifier. Ironmak. Steelmak. 2017, 45, 1-7. [CrossRef]

17. Pal, S.; Lahiri, A.K. Mathematical model of COREX melter gasifier: Part I. steady-state model. Metall. Mater. Trans. 2003, 34, 103-114. [CrossRef]

18. Liu, X.L.; Pan, G.; Wang, G.; Wen, Z. Mathematical model of lump coal falling in the freeboard zone of the COREX melter gasifier. Energy Fuels 2011, 25, 5729-5735. [CrossRef]

19. Lee, S.C.; Shin, M.K.; Joo, S.; Yoon, J.K. The effects of operational parameters on the transport phenomena in COREX melter-gasifier. ISIJ Int. 2000, 40, 1073-1079. [CrossRef]

20. Sun, J.; Wu, S.L.; Kou, M.Y.; Shen, W.; Du, K.P. Influence of operation parameters on dome temperature of COREX melter gasifier. ISIJ Int. 2014, 54, 43-48. [CrossRef]

21. Du, K.P.; Wu, S.L.; Zhang, Z.K.; Chang, F.; Liu, X.L. Analysis on Inherent characteristics and behavior of recycling dust in freeboard of COREX melter gasifier. ISIJ Int. 2014, 54, 2737-2745. [CrossRef]

22. Wang, H.Y.; Zhang, J.L.; Wang, G.W.; Zhao, D.; Guo, J.; Song, T.F. Research on the combustion characteristics and kinetic analysis of the recycling dust for a COREX furnace. Energies 2017, 10, 255. [CrossRef]

23. Sun, Y.; Di, Z.X.; Li, H.F.; Luo, Z.G.; Zou, Z.S. Numerical simulation of temperature in the freeboard of COREX melting gasifier. Adv. Mater. Res. 2011, 285, 1165-1169. [CrossRef]

(C) 2018 by the authors. Licensee MDPI, Basel, Switzerland. This article is an open access article distributed under the terms and conditions of the Creative Commons Attribution (CC BY) license (http:/ / creativecommons.org/licenses/by/4.0/). 